\title{
Anesthesia standards for facilities and equipment
}

Purpose: This article will define standards, how they are developed and applied and how they impact on the day to day practice of clinicians.

Source: CSA-International, International Electrotechnical Committee (IEC), O rganization for International Standardization (ISO).

Principal findings: The safety record of the practice of anesthesia has improved over the past $20 \mathrm{yr}$. This has been brought about by the increase in the knowledge base of physiology and pharmacology, improvements in anesthetic drugs and other medications and through the use of better equipment. However, the introduction of new equipment and the building of new health care facilities has also introduced risks to patient safety. These risks have been created by oversights in design, mistakes in equipment manufacture or facility construction and the need to produce a usable product for the price the health care system can afford. After the anesthetic disasters of the 1960s and 1970s, the need for minimum standards for safety in the design and construction of healthcare facilities and medical equipment were recognized. Canadian anesthesiologists were at the forefront in the development of these standards, and still today members of the Canadian Anesthesio logist's Society are key contributors to the development of both $\mathrm{N}$ ational and International standards.

Conclusion: Equipment and facility standards have helped improve patient safety over the past $20 \mathrm{yr}$. However, anesthesio logists need to encourage their governmental regulato ry bo dies to encourage manufacturer compliance with specific standards.

O bjectif : Définir les normes, décrire comment elles sont mises au point et appliquées et quel est leur impact sur la pratique clinique quotidienne.

Source : L'ACN O R-Internationale, la C omission électrotechnique internationale (CEI) et l'O rganisation internationale de normalisation (ISO).

Constatations principales : La sécurité dans l'exercice de l'anesthésie s'est améliorée au cours des 20 dernières années. C'est grâce aux meilleures connaissances de la physiologie et de la pharmacologie, aux amélio rations des médicaments anesthésiques et d'autres médicaments et à l'usage d'un matériel de meilleure qualité. Cependant, l'introduction de nouveau matériel et la construction d'installations comportent d'autres risques à la sécurité du patient. Ces risques ont été créés par des erreurs de design, de fabrication de matériel ou de construction d'installation et par la nécessité de réaliser un produit utilisable à un prix abordable pour le système de santé. Après les désastres anesthésiques des années 1960 et 1970, on a reconnu la nécessité de normes minimales de sécurité dans le design et la construction d'installations de soins et de matériel médical. Les anesthésiologistes canadiens ont été au premier plan du développement de ces normes et, encore aujourd'hui, les membres de la Société canadienne des anesthésiologistes sont des collaborateurs importants au développement de normes nationales et internationales.

Conclusion : Les normes pour le matériel et l'aménagement ont contribué à l'amélioration de la sécurité des patients depuis 20 ans. Mais, les anesthésiologistes doivent inciter les instances de contrôle gouvernementales à encourager l'adhésion des manufacturiers à des normes spécifiques. 


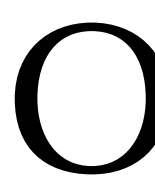

NE morning in August 1973, a six-yearold girl fell from a swing at her grandmother's home and badly fractured her leg. She was taken to the hospital $50 \mathrm{~km}$ away, where she died during surgery. Five months later, a coroner's jury ruled that the girl had died "due to administration of nitrous oxide following an anesthetic." A fatal error in the hospital's medical gas pipeline system resulted in the administration of nitrous oxide $100 \%$ during emergence instead of oxygen $100 \%$ The jury also found that the same problem had either caused or contributed to eight other deaths at the hospital in $1973 .^{1}$

A 53-yr-old woman entered a hospital to have a bunion removed from her toe. A coroner's jury later found that an improperly installed valve in the anesthetic machine caused anoxic encephalopathy that led to her death. ${ }^{1}$

There are many different types of standards in the world today. Everyone has noticed the CSA mark on the back of household appliances, stereo systems, children's bicycle helmets and anesthetic and critical care equipment. Anesthesiologists also have standards of practice for patient care, but what are these standards about, who writes them, and what do they mean in our daily practice of medicine? In this article, I will describe the purpose of equipment standards, how they are written, how they should be applied, their legal status and address the current issues surrounding anesthesia, respiratory care and critical care equipment standards, their advantages and limitations.

\section{Definitions}

Standards are documented agreements containing technical or performance specifications or other precise criteria to be used consistently as rules, guidelines, or definitions of characteristics, to ensure that materials, products, processes, and services are fit for their intended purpose. Some standards establish levels of performance of equipment, some constructional requirements; some guide business management practices (ISO 9000 series) whereas others address social and environmental concerns (ISO 14000 series).

Within Anesthesia and $\mathrm{C}$ ritical $\mathrm{C}$ are there are three types of standards:

1. Safety standards that set minimum requirements for electrical safety and usability. These requirements include, but are not limited to, specifications for leakage current, how the equipment will react to electromagnetic radiation, for example from cell phones and electrocautery machines, and requirements for how equipment is protected against spills and tip-over stability tests.
2. Performance standards that set minimal requirements for equipment performance during use.

3. Technical reports that provide guidance to manufacturers and users for equipment design, construction, performance and use.

Standard development

Standards are developed by technical committees, subcommittees and working groups made up of representatives of manufacturers, equipment users, operators, and other interested parties using a consensus approach. The process usually starts when a request is made from a manufacturer, industry association, consumer group, educational institute, or governmental body to help with a particular safety, performance, or quality issue.

Initial drafts are written by working groups or adapted from similar standards from other countries or from standards of similar equipment. M embers from national committees are asked to comment and vote on these drafts. The normal progression of the drafts include working drafts to which comments and corrections can be made, draft standards for comment, and then final drafts which are voted on to accept or reject only. (Figure 1)

The key attributes of standards are that they:

- are developed by a consensus-based multi-stake holder process;

- stipulate the minimum requirements that a product, process or service must meet; and

- are prepared under the auspices of a recognized standards development organization.

$M$ ost of the anesthesia and critical care standards are written by the Organization for International Standardization ISO Technical Committee 121 Anesthesia and Respiratory Equipment (ISO TC121) and its subcommittees, International Electrotechnical Commission IEC Committee 62 and in Canada, the CSA-International Committee Z251 (Table I, Figure 2). ISO TC 121 first met in London UK in $1967^{2}$ and adopted the British standard of $15 \mathrm{~mm}$ and $22 \mathrm{~mm}$ for breathing system connections. The Canadian Anesthesiologists' Society has representatives on the

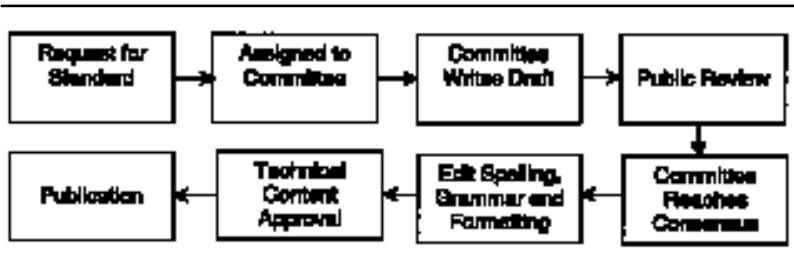

FIGU RE 1 Flowchart for inception and development of a standard 
TABLE I CSA International Committees

Technical Committee: Z251

Technical Subcommittee TSC 1 - Anesthetic Equipment: Z251.2

Technical Subcommittee TSC 3 - Respiratory Technology: Z251.1

Technical Subcommittee TSC 6 - M edical Gas Systems: Z251.20

There are also three Task Forces, under the following numbers:

Transport Ventilators: Z251.10

H ome Care Ventilators: Z251.12

Portable O xygen Systems: Z251.12.1

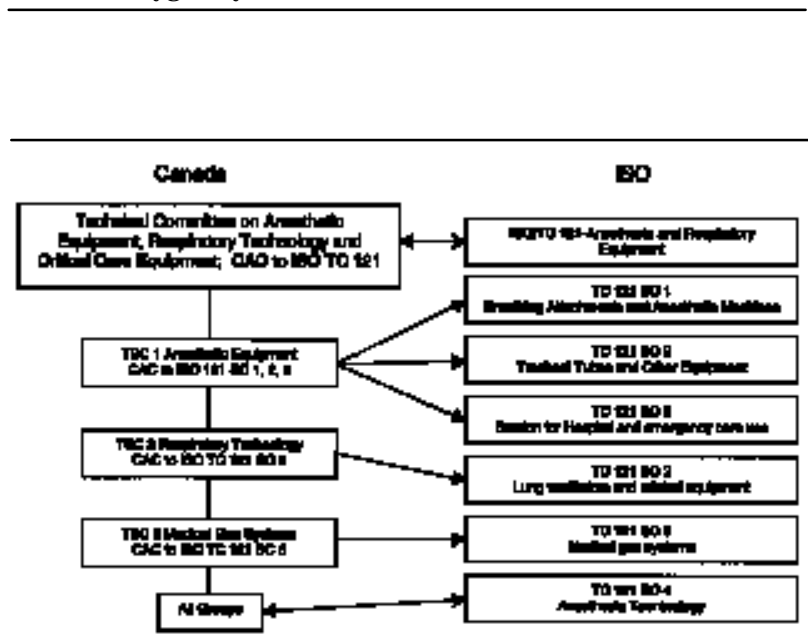

FIGU RE 2 CSA International and ISO Committees In Canada, national committees for anesthesia and respiratory standards also participate in ISO standards development work as Canadian Advisory Committees (CAC)

CSA International, ISO and IEC Committees. These anesthesiologists bring an important clinical perspective to these committees that are largely made up of engineers from the various equipment manufacturers. The opinions of anesthesiologists and intensivists are very highly regarded by the manufacturers who have little practical experience with equipment within the operating room and critical care settings.

Who are the standards bodies and organizations?

In Canada, the Standards Council of Canada (SCC) is the clearinghouse for all standards. The SCC is a federal crown corporation with the mandate to promote efficient and effective standardization. The Standards Council of $\mathrm{C}$ anada coordinates the writing of $\mathrm{C}$ anadian $\mathrm{N}$ ational Standards for which there are no international standards available, or through its committees decides which International Standards should be adopted as $\mathrm{C}$ anadian $\mathrm{N}$ ational Standards. These $\mathrm{C}$ anadian committees may decide to change these international standards when they are adopted for use in Canada.
TABLE II Standards O rganizations

\begin{tabular}{|c|c|c|}
\hline Abbreviation & Standards O rganizaton & Website \\
\hline $\begin{array}{l}\text { SCC } \\
\text { CSA }\end{array}$ & $\begin{array}{l}\text { Standards Council of Canada } \\
\text { CSA I nternational }\end{array}$ & $\begin{array}{l}\text { www.scc.ca } \\
\text { www.csa-interna } \\
\text { tional.com }\end{array}$ \\
\hline ISO & $\begin{array}{l}\text { Organization for International } \\
\text { Standardization }\end{array}$ & wWw iso ch \\
\hline IEC & International Electrotechnical & \\
\hline CEN & $\begin{array}{l}\text { Commission } \\
\text { Committee for European }\end{array}$ & www.iec.ch \\
\hline & N ormalization & www.cenorm.be \\
\hline UL & Underwriters L aboratories & \\
\hline U LC & $\begin{array}{l}\text { U nderwriters } L \text { aboratories } \\
\text { Canada }\end{array}$ & \\
\hline ASTM & $\begin{array}{l}\text { America Society for Testing } \\
\text { of } M \text { aterials }\end{array}$ & www.astm.org \\
\hline NFPA & $\mathrm{N}$ ational Fire Protection & \\
\hline \multirow{3}{*}{ ANSI } & Association & www.nfpa.org \\
\hline & American $\mathrm{N}$ ational Standards & \\
\hline & Institute & www.ansi.org \\
\hline
\end{tabular}

There are numerous standards writing committees and organizations throughout the world (Table II). As anesthesiologists in Canada, we use the standards of the CSA International, the Organization for International Standardization (ISO), the International Electrotechnical Commission (IEC), and the Compressed Gas Association (CGA). In the U nited States the anesthetic and critical care Committee F29 of the American Society for Testing and $M$ aterials (AST M ) writes the standards. In Europe the standards body is known as CEN and their marking is CE. In Japan, their standards body is the Japanese Industrial Standards Committee (JISC).

The International O rganization for Standardization (ISO), a worldwide federation of national standards bodies, comprises more than 127 member countries. The goal of ISO is to promote the development of global standardization and related activities, thereby encouraging international trade and cooperation among countries across a range of intellectual, scientific, technological and economic activities.

The International Electrotechnical Commission (IEC) has 42 member countries that account for $80 \%$ of the world's population and $95 \%$ of its electrical energy production. $M$ embers are drawn from the principal standardization bodies at the national level. The IEC maintains advisory committees on electromagnetic compatibility, electrical, medical, and telecommunications electronics safety.

\section{CSA International}

The best known standards organization in Canada is CSA International. CSA International (formerly the 


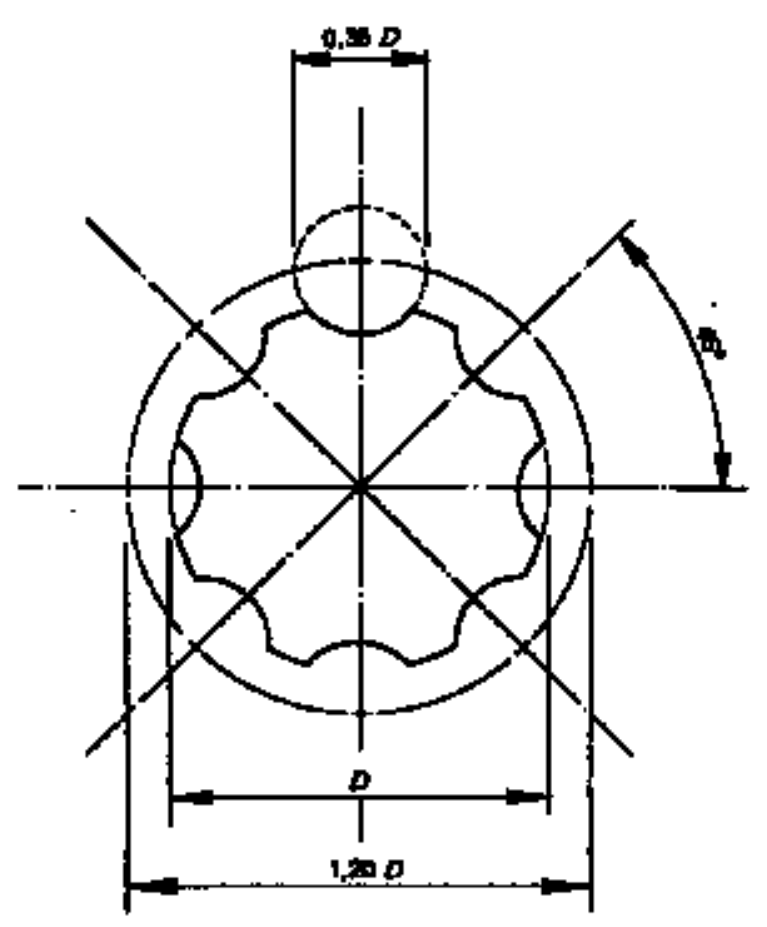

FIGU RE 3 Drawings from CAN / CSA Z168.3 Anaesthesia $M$ achines for $M$ edical $U$ se demonstrating the standard specifica tions for the construction of the oxygen flow control knob for anesthetic machines (U sed with permission CSA I nternational). Copyright CSA International, 178 Rexdale Boulevard, Toronto, O ntario M 9W 1R3. While use of this material has been authorized, CSA International shall not be responsible for the manner in which the information is presented, nor for any interpretations thereof.

Canadian Standards Association) is a non-governmental, private sector, not for profit corporation with over 8,000 members and a network of offices worldwide. CSA International provides two functions: (1) to sponsor and facilitate the development of standards for products and services, and (2) as a test house to test individual pieces of equipment or certify business management practices to ascertain whether they comply with their respective standards. Q MI, a wholly owned subsidiary specializes in the management systems registration for the ISO 9000 series of standards. CSAInternational is a global leader in development and certification of equipment standards. In addition, they are in partnership with more than 30 international standards organizations. They are a recognized certification body for the IEC, maintain their own electromagnetic compatibility (EMC) laboratory, and have an explosive atmospheres lab. The EMC laboratory, for example, could test for possible problems with medical equip-

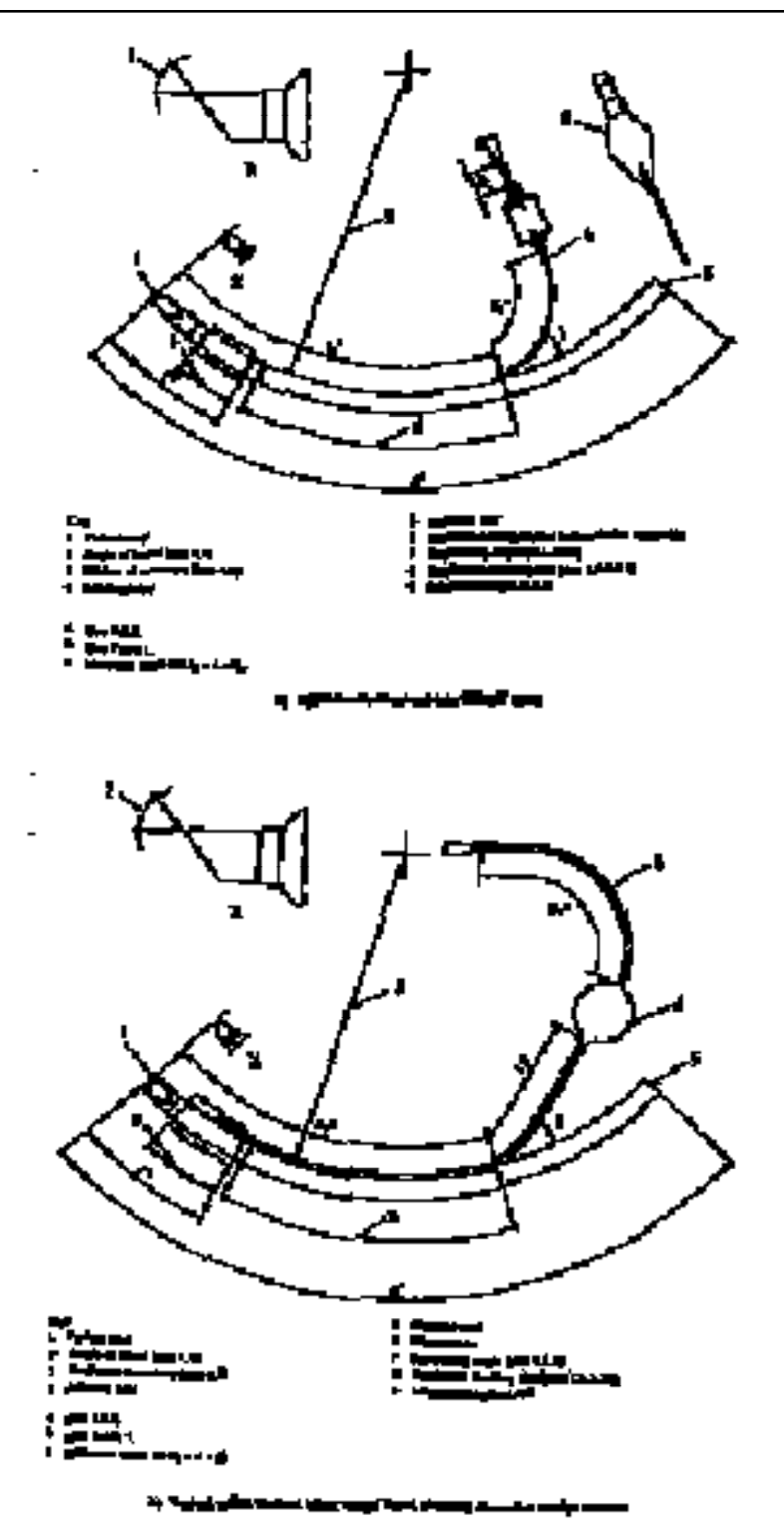

FIGURE 4 Drawings from CAN/ CSA Z5361 demonstrating the standard specifications for the construction of the endotracheal tubes. (U sed with permission CSA International).

Copyright CSA International, 178 Rexdale Boulevard, Toronto, O ntario M 9W 1R3. While use of this material has been authorized, CSA International shall not be responsible for the manner in which the information is presented, nor for any interpretations thereof.

ment in close proximity to cellular telephones.

The first CSA standard in the health care area was published in 1963 to deal with the problem of explosions in hospital operating rooms involving flammable anesthetic agents. The C SA Z32-1963 Code for U se of Flammable Anesthetics effectively reduced the principal 
hazard (involving medical equipment) of that era. 0 ther standards followed: a standard for endotracheal tubes in 1963, for endotracheal tube connectors in 1967, the Code for Prevention of Explosions and Electric Shock in H ospital O perating Rooms in 1970, and a standard for non-flammable medical gas piping systems in 1973.

A major impetus to the expansion of health care standards activities was the report, Clinical L aboratory and Electromedical Equipment Study issued in 1973 by CSA and the Federal Department of $\mathrm{H}$ ealth. The study confirmed that doctors and hospitals were experiencing difficulties in coping with the profusion of medical devices. O ne major direct result of the 1973 study on laboratory and electromedical equipment was the establishment that year of CSA's H ealth Care Technology program. ${ }^{1}$ The technical drawings for the standard anesthesia machine oxygen knob (Figure 3) and endotracheal tubes (Figure 4) are examples of equipment that are very familiar to anesthesiologists.

What is the CE on all the equi pment and packages? As of July 1, 1998 all medical devices sold and used in the European U nion must bear the CE mark. ${ }^{3}$ The CE (Conformité Europeene) mark shows that the equipment has been type tested and manufactured in compliance with European Standards as written by CEN . Type testing means that one item of each of the models of equipment were tested for compliance. In addition, medical equipment must also comply with IEC 60601-1-2 on electromagnetic compatibility. ${ }^{4}$ To use the CE mark, a manufacturer must apply for approval to an organization called a notified body. A four-digit number accompanying the $C E$ identifies which notified body was consulted. If a CE mark appears without a notified body mark, it is likely that the device only complies with the electromagnetic compatibility standard. The electromagnetic compatibility standard specifies requirements that minimize the amount of electromagnetic radiation that a device emits which may interfere with the functioning of other equipment and also sets minimum requirements for shielding of equipment from electromagnetic radiation.

\section{R eading standards}

Standards, like many legal documents, have a language of their own. The term "shall" denotes a requirement and means that compliance with a requirement is mandatory. All "shall" clauses are followed by a test to check for compliance. Statements using the term "should" designates that compliance with a requirement or a test is recommended but not mandatory for compliance with the standard. The term "may" is used to describe the permissible way to achieve compliance with a requirement or a test. O ften written into the standards are requirements for the hospitals and for the people actually using the equipment. The term "user" is defined as the authority responsible for the use and maintenance of the equipment whereas the "operator" is the person actually handling and operating the equipment. In the case of home care equipment the user and the operator may be the same person.

\section{Certification}

Before sale, all manufacturers submit their equipment to "test houses" for certification of their equipment's performance to a particular standard. These "test hous es" include but are not limited to CSA International, U nderwriters Laboratories, ETL, and Entela.

\section{A dvantages of standardization}

Standards attempt to improve the health and safety of the anesthesiologist, other healthcare providers and the patient. They attempt to enhance equipment quality and reliability at a price that the health care system can afford. Standards facilitate training of anesthesiologists, as a particular type of equipment is similar between models and manufacturers. Standards provide greater compatibility and interoperability of equipment across different models and different manufacturers and hopefully, standards lead to simplification of equipment for improved usability and ease of maintenance.

In the growing global economy, international standards facilitate trade between countries. As the world shrinks with the internationalization of trade, there is a need for global harmonization of existing standards. As Canada is a relatively small country, it is in our best interests to harmonize our national standards with international standards, as either manufacturers will not specifically design and build equipment for sale only in the small Canadian market or we will be unable to afford the price of $\mathrm{C}$ anadianized equipment.

\section{Shortfalls of standards}

The greatest disadvantage of standards is that they specify only minimum requirements for safety. The major limitation of standards, however, is that in Canada and many other countries, manufacturer compliance with existing standards is voluntary when designing equipment. It is up to the manufacturer to decide whether they wish to apply each of the applicable standards for each piece of equipment. Manufacturers are not required by law to manufacture equipment compliant to standards written for particular pieces of equipment unless mandated by a provincial or national electrical code. The $\mathrm{C}$ anadian electrical code requires compliance 
TABLE III Some standards to which anesthetic workstations should be compliant

IEC 60601-1 Medical electrical equipment - Part 1: General requirements for safety

IEC 60601-1-2 M edical electrical equipment - Part 1: General requirements for safety - 2. Collateral Standard: Electromagnetic compatibility - Requirements and tests

IEC 60601-1-4 M edical electrical equipment - Part 1: General requirements for safety - 4. Collateral standard: Programmable electrical medical systems

IEC 60601-2-13 M edical electrical equipment - Part 2-13: Particular requirements for the safety of anesthetic workstations

IEC 60601-2-27 M edical electrical equipment - Part 2: Particular requirements for the safety of electrocardiographic monitoring equipment

IEC 60601-2-30 M edical electrical equipment - Part 2: Particular requirements for the safety of automatic cycling indirect blood pressure monitoring equipment

IEC 60601-2-34 M edical electrical equipment - Part 2: Particular requirements for the safety of direct blood pressure monitoring equipment

ISO 9703 Parts 1,2 Anaesthesia and respiratory care alarm signals

ISO 8835-1 Inhalational anaesthesia systems - Part 1: Anaesthetic workstations and their components - Particular requirements

ISO 9918 C apnometers for use with humans - Requirements

ISO 9919 Pulse oximeters for medical use - Requirements

ISO 11196 Anaesthetic gas monitors

ISO 14971 M edical devices - Risk management - Application of risk management to medical devices

ISO 7767:1998 Oxygen M onitors for monitoring patient breathing mixtures-safety requirements

with CSA 22.2 Number 125 , or CSA C22.2 No. 601.1 . N umber 125 is slowly being phased out and $\mathrm{N} o$. 601.1 will take its place. It is the Canadian adaptation of IEC 60601-1 usually referred to as the "General Standard" and provides electrical safety requirements, tip-over tests, spill tests and other safety related requirements. Ethical equipment manufacturers usually meet and exceed the requirements of these standards.

Recent issues involving standards

There is some confusion as to what the CSA mark on the back of a piece of equipment means. It is not a requirement that the manufacturer lists the standard numbers to which the equipment was tested on the sticker. It is the responsibility of the purchaser of equipment to ask the manufacturer to which standards the equipment is compliant. All manufacturers within their accompanying documents must state to which standards their equipment is compliant, but they often do not. U sually, the CSA sticker only represents compliance with the $C$ anadian electrical code.

For example, in the case of an older conventional anesthetic machine, the machine must meet the requirements of CSA $22.2 \mathrm{~N} 0.601 .1$ or $\mathrm{N} 0.125$ but does not legally need to meet the requirements of CSA Z168.3 Continuous-Flow Inhalation Anaesthetic Apparatus (Anaesthetic $M$ achines) for $M$ edical $U$ se.

The purchaser of equipment, however, must also be aware that not all pieces of equipment have particular performance standards. There is no Canadian standard for the new Anesthesia workstations. "Anesthetic workstation" is the generic term for equipment that delivers anesthetic agents, has an integrated ventilator and physiological multiparameter monitors. The major advantage of these workstations is that they are well integrated units with fewer hoses and wires dangling from them, and all the alarms are located in one location. Workstations facilitate automated recordkeeping as all the data are from one source. Some of these anesthetic workstations have been designed to currently available IEC, European CEN and American ASTM standards.

In addition to the anesthetic workstation standard, the workstation should also be compliant with a number of other standards. These include, but are not limited to those in Table III.

Anesthetic vaporizers are generally covered by two standards. The first covers the construction and performance of non-electronic vaporizers; the second specifies the agent specific filing tubes. The desflurane vaporizer does not have a specific CSA construction or performance standard. I ts CSA certification only refers to its electrical safety and not its performance. Recently, anes thetic agent vaporizers have been marketed with nonCSA approved agent specific filling tubes. These filling tubes are patented by their manufacturer and, therefore, are ineligible for CSA approval unless the manufacturers relinquish their patent rights. This does not mean that they are necessarily less or more safe than conventional filling tubes. It is the responsibility of the manufacturer of these filling tubes and vaporizer adapters to ensure their safety and performance through their design, manufacturing and risk assessment processes. The CSA approval on these particular non-electronic vaporizers refers only to the vaporizer construction and its performance and not to the filling tube.

Equipment can only comply with the standards that are available at the time of their design. As it takes sever- 
al years to design equipment and for the regulatory agencies to approve it for use, when the equipment is ultimately available for use, the standard to which it is compliant may no longer be the current edition of the standard. Similarly, as standards take several years to develop, the rapidly evolving technology may often overtake them. Thus standards' writers must be cognizant of the need to write standards that will not stifle innovation.

$O$ ver the years, each nation has developed its own standards. U ntil recently, anesthesia and critical care equipment produced by a single manufacturer had to adhere to the standards of all the countries in which the equipment was distributed. The proliferation of incompatible national standards greatly increases the cost of equipment. For example, the colour code for oxygen is white in $\mathrm{C}$ anada, green in the $\mathrm{U}$ nited States and blue in Germany! Fortunately for $\mathrm{C}$ anada, we al ready are using the ISO 32 white colour code for oxygen. Since the creation of the European Economic Community and the $\mathrm{N}$ orth American Free Trade Agreement, global standards are now being harmonized so that manufacturers in the future will only have to manufacture equipment to one international standard.

For example, there are three standards worldwide for anesthetic workstations and critical care ventilators. A joint working group of ISO, IEC and CEN is working to harmonize standards to replace these six standards with two standards. As there are limited resources in Canada for producing a new anesthetic workstation standard, it is probably in our best interest to wait for a new international standard to be developed. The $\mathrm{C}$ anadian opinions, however, are not lost as there are $C$ anadian representatives on these international joint-working groups.

To try to simplify and minimize the confusion of multiple standards, the CSA-International Committee Z251 meets on a regular basis to review international standards and advises the SCC on which standards to adopt as Canadian National Standards. A listing of all the CSA standards for Anesthesia and C ritical Care equipment is provided in the Canadian Anesthesiologists' Society Annual M embership List and Standards of Care edition as well as on the member's section of the CAS Website.

Standards have made anesthesia and critical care equipment much safer over the years. All hospitals should own copies of the CSA-International, ISO or IEC standards for the equipment that the hospital utilizes. These standards may be purchased from CSAInternational, the Standards Council of Canada or directly from the ISO or IEC. Some standards are available as Adobe Acrobat portable document format (pdf) files and may be purchased and downloaded from the web sites listed in Table II.
It is the responsibility of the purchaser of equipment to be aware of the value and limitations of standards on the equipment that they purchase. They should be clear about to which standards the prospective piece of equipment is compliant. When purchasing equipment, the purchase order should state that the equipment shall meet the requirements of the Canadian or provincial electrical codes and other particular equipment standards if available and if applicable. 0 nly by requiring compliance with standards, will manufacturers be forced to comply with them. The Canadian Anesthesiologists' Society and CSAInternational representatives are willing to discuss any concerns that Anesthesiologists, Intensivists, Respiratory Therapists or others have about the design and safety of equipment in C anada.

Building awareness and understanding of standardization and the important contribution it makes to Canadians' social and economic well-being is critical to the long-term success ... of Canada's standardization efforts. An informed public, with a solid understanding of the benefits and appropriate use of standardization processes, will help to ensure that decision-makers in both government and industry give full consideration to standardization as an important tool for shaping policies that meet the needs of the Canadian public and industry". ${ }^{5}$

\section{Acknowledgements}

The author wishes to thank $\mathrm{C}$ atherine $\mathrm{H}$ awke and J effrey Kraegel for their assistance in the preparation of this manuscript, and Drs. J. Sloan, J. HedleyWhyte, R. Greenbaum and M r. D. O sborn for their expert advice.

\section{References}

1 Gray E. H ealth care technology: a quest for safety and quality. Standards Forum U pdate Canadian Standards Association, Winter 1983.

2 Greenbaum R. The breath of Life. ISO / TC 121, Anaesthetic and respiratory equipment, breathes optimism and reaps results. ISO Bulletin, J anuary 1997; 28: 11-4.

3 Council Directive 93/ 42/ EEC of 14 June 1993, concerning medical devices. O fficial Journal of the European Communities 1993; L 169: 1-43.

4 International Electrotechnical Commission. M edical electrical equipment. Part 1: General requirements for safety. 2. Collateral standard: electromagnetic compatibility - requirements and tests. IEC 60601-1-2.

5 Standards Council of Canada, Canadian Standards Strategy. D ecember, 1999. 